\title{
The impact of spiritual leadership on empowerment and work procrastination
}

\author{
Arif Damar ${ }^{1 a}$, and Ersin Eskiler ${ }^{2}$ \\ ${ }^{1}$ School of Applied Sciences, Department of Accounting and Auditing, Bilecik Seyh Edebali \\ University, 11300 Bilecik, Turkey \\ ${ }^{2}$ Faculty of Sport Sciences, Department of Sport Management, Sakarya University, 54050 Sakarya, \\ Turkey
}

\begin{abstract}
How will employees who get away from society because of factors such as increasing work intensity with globalization, rapid consumption by impact of capitalism, mechanized organizational structure due to technological development and momentary satisfaction through easy access to information, ensure that organizations maintain their existence, protect their level of competitive and make profits on the average? In this context, the aim of the present study was to investigate the effects of spiritual leadership on employee empowerment and work procrastination in organizations. A questionnaire was applied face-to-face to the employees of the private sports-fitness center operating in Sakarya by using judicial sampling method within the scope of the study. As a result of the analysis of the obtained data; it was determined that there was low and positive relationship between "meaning/call" which was the sub-dimension of spiritual leadership, discretion and responsiveness which was the sub dimensions of empowerment. Adoption of work by employee, sense of belonging to work and meaning of the work can produce solutions without the approval of the managers and meet the requests and needs. A negative relationship was determined between altruistic love which was the subdimension of spiritual leadership and work procrastination. The managers who are honest, consistent, courteous and look after employees' rights provide them not to delay their works. One of the important findings of the research is that individuals who have the control in their works will develop their self-confidence however they could delay their work. Keywords: Empowerment, spiritual leadership, procrastination.
\end{abstract}

\section{Introduction}

The human is one of the indispensable elements of production resources, which will increase the competitiveness of enterprises and provide competitive advantage. Actually, to attach importance to people means to care about enterprise. The value, authority and

a Corresponding author: arifdamar@yandex.com 
responsibility given to employees, and participation in decisions will be facilitated objectives predetermined. However, it will not be possible for employees to increase their productivity and efficiency levels alone under changing environmental conditions. It will ensure that employees find their jobs meaningful, thanks to the leaders who create the values, attitudes and behaviors and who motivate themselves and their employees in the direction of the objectives of the enterprises. Employees who are given authority and responsibility by their managers, who see that they make a difference, will adopt their works and try to do their best for their own purposes and goals. Therefore, the employees will be able to fulfill their work on time with pleasure and without delay and getting bored. Managers will improve employees' productivity, and efficiency by giving confidence and valuing their employees.

The employees really believe that managers are fair and they respect their courtesy and ideas, will enable employees to adopt the work they do, feel themselves belong to organization, increase their belief in the organization's mission and vision, and move comfortably without the approval and idea of the manager. In addition, they will continue their competitive superiority with their beliefs, comfort and creative ideas.

\section{Conceptual framework}

\subsection{Spiritual leadership}

Today, it is getting harder day by day to adapt to rapidly changing resources and conditions. For this reason, leaders are needed, who are not afraid of making decision, who can take risks, who care about not only themselves but also group as a whole. In this context leadership is to increase the degree of harmony with environment and people you work with.

Despite the development of various leadership definitions in the studies, it is possible to say that it has not been reached a consensus on the subject. The concept of leadership thought to be derived from the word "lira", which means furrow in Latin, is the creation of conditions under which self-organizing or self-learning can take place [41]. The concept that has not lost its significance throughout history and has an Anglo-Saxon origin, has entered the academic literature in the 14th century. It is a phenomenon that is seen in every developed and underdeveloped human community [4], especially in the 1950s, where indepth studies have been made about the concept that has become a current [23]. There is a merit at the core of leadership. Namely, it is to be worthy, to benefit, and to be able to perform a task successfully [7]. In this context, leadership is the ability to make others accept its will and requests by earning their respect, trust, obedience and commitment [38]. In recent years, the concept of spiritualism has become so popular because of many factors such as the rapid consumption of capitalism by the widespread use of the internet, momentary satisfaction through easy access to information and loneliness felt by the individual and isolation from society, stress and so on [6]. Industry revolution that reduces dependency on nature has made it difficult to explain the concept of spirit and spirituality by making organizations more uncontrolled and incomprehensible with traditional, decentralized, standardized, formal bureaucracy-based and fear-based insights [1]. The concept of spirituality has not been considered in the organizational sense, and psychology discipline has been more concerned with it [19].

Soul is expressed as the essence, the life bird that religions and religious philosophies regard as a separate entity from the human body (tdk.gov.tr). It comes from the Latin word "spiritus" which means breath [22], and is defined as the power necessary for survival [6]. The spirit, which is an invisible power that gives us life, energy and inspiration, is hidden in 
individuals and organizations [1]. In this regard, spirituality represents an inseparable part of the identity of the person who is influential everywhere, including the workplace and a part of the center of the individual's worldview [44].

In the most general sense, spiritual leadership is "the process of touching the basic needs of both himself and his followers for spiritual prosperity, defining the values, attitudes and behaviors necessary to motivate them, creating a shared vision and value by creating a strengthened team spirit, and ultimately increasing productivity and loyal commitment through belonging" $[13,15]$.

Spiritual leadership consists of 5 dimensions: vision, altruistic love, hope/faith, meaning/calling, membership [13, 28]. The altruistic love is expressed as favour, harmony and integrity that arise through interest and anxiety and as care for themselves and others. Hope is the desire to perform the work while faith is more than desirable. Assurance of hope is to believe in invisible [13]. Vision is a photo that reflects the goals and objectives of organizations desired to perform in the future [7]. Hence, a vision is needed to encourage and challenge employees to do their best [14]. Employees' work and life are meaningful when they are motivated and feel to be useful at work [32]. Membership is stated as the feeling of being a member of the organization who are understood and appreciated by the managers [19].

\subsection{Empowerment}

Today, in the face of changing competition conditions, customer expectancies, consumer needs and demands, organization are no longer interested only in maintaining their presence, they want to make a profit on the average, and even to gain a competitive advantage in the market. Therefore, organization help the worker to improve the quality of their work and to adopt their work as their own by educating, developing, increasing their authority and responsibilities, enabling them to participate in decisions and to take the initiative in what they do, on the basis of human resource management. In fact, the power is defined as "a motion that causes an event and ability to resist" according to Turkish Language Association but is described as affecting the behavior of others in the direction of their own goals and objectives [38]. The concept of empowerment in the context of management is asserted to have firstly emerged in the writings and philosophies of American political scientist Follet at beginning of 19th century [20, 40].

Researches on the concept of empowerment defined as the basic component of organizational and managerial effectiveness; began with Founder of Scientific Management, Taylor's motion and time study in the 1920s [24] and are considered as a cognitive situation and a managerial approach [25]. Later, Elton Mayo against Taylorism, revealed that employees' morale can be improved by ensuring employee participation in decisions and work, and suggest that employees can do a good job on their own accord without close supervision [5].

The concept of empowerment is defined and expressed in various forms in the fields of organizational behavior, human resources, management and psychology. These are "authorization", "employee empowerment", "personnel empowerment", "psychological empowerment", "structural empowerment" and "organizational empowerment" [40]. Empowerment is defined as the attainment of personal success through the restructuring of attitudes and the redistribution or transfer of decision-making authority to those who do not have that authority [9].

In general, empowerment is expressed as employees have more authority to carry out their tasks and take initiative in solving all problems related to their work [47]. In essence, empowerment refers to the transfer of authority and responsibility to subordinate by the superiors [2]. 
Several researchers have created dimensions of empowerment from different perspectives. These are payment systems that link a worker's self-control, self-mastery, diversity of teamwork, and wages and performance [21]. In addition, Spreitzer created four dimensions (meaning, competence, autonomy, and influence) that reflect the active state, not the work-oriented passive orientation of employee empowerment [25].

The success or failure and implementation of empowerment cultures at organizational level depends on organizational factors such as structure, culture and size. Here, changes at the organizational level are needed to be considered holistically not as micro or macro factors alone but as rewarding, training, giving new responsibilities, ensuring participation in decisions, work structure, organizational culture and so on. It is a complicated process to evaluate willingness and desire of employees to be empowered and whether they accept the responsibility for them or not. As such, managers directly encourage their employees to be empowered and take great responsibility for the successful implementation and long-term adoption of empowerment [3].

\subsection{Procrastination}

Procrastination is occurred due to reasons such as increased work intensity, failure in standard business planning, not being able to use time well, difficulty in decision making, personality traits, to postpone the works for the last minute, not to have business-related control, to be afraid of taking responsibility.

This concept, origin in Latin, is based on "pro" which means forward, forth, or in favor of," and "crastinus" which means "tomorrow" [35], is expressed as postponement, delay of a decision or task, conceptualized similarly to researchers. Procrastination is defined as delaying a task that is under an individual's control, where the delay is under the control of the individual, and task that must be completed [43]. Procrastination is an unreasonable delay that we have voluntarily delayed our tasks, even though it is thought or known that it will lead to bad results [36]. In general, it can be expressed as preferring a task with a lower priority instead of a task with a higher priority [42]. In fact, postponement is sometimes used in positive meanings as functional delay or avoidance from rush [35].. Postponing is the act of postponing the execution of a task, usually postponing a task that feels discomfort [8]. Those who see themselves as those who postpone work try to complete their work on time by setting realistic goals and deadlines in order to complete their tasks within a reasonable amount of time [17]. However, this creates stress on them and therefore, has negative consequences, such as poor performance and low productivity at work [37, 39 and 43].

Procrastination is associated with poor academic performance, low self-esteem, high stress, and high levels of anxiety [26]. Ferrari [11] argues that postponement can be seen as a time delay in task performance and that emotional, behavioral and cognitive elements play a role in procrastination. Researchers have associated the procrastination of tasks for the protection of defenseless self-esteem with the behavioral dimension, deliberately delaying the related task with the cognisitive dimension, and worrying about the anxiety and physical symptoms with the emotional dimension $[12,33]$.

\subsection{Relations between spiritual leadership, empowerment and work procrastination}

Organizations today are made up of very complicated, ambiguous structures, rules created by the internal and external environment. Accordingly, organizations operating in such an environment should give the value the employees deserve to them. Employees want to feel important and valuable and to be understood by their managers. In this context, spiritual 
leaders are needed as motivators who understand employees. Seaborne [34] emphasizes in his work, that flexible leadership style enhances employees' ability, motivation, and commitment and so empowered employees will do their work in a quality, effective and productive way. Besides Yaghoubi, Moloudi and Banihashemi [45] has found that spiritual leadership has a positive influence on personnel empowerment but that leader-performance feedback is more important than other dimensions of spiritual leadership. That is, the high performance at the workplace can be explained as the employees are satisfied with the organizational environment.

Moradi and Shayestehpour [30] shows that his spiritual leadership has a positive influence on personnel empowerment. However, organizational efficiency and productivity are negatively affected by personnel who do not perform their jobs on time, constantly delay their works and postpone their works for the last minute [46]. However, the managers who understand the employee, make them valuable, give authority and responsibility and increase the motivation will help the employees to adopt their work. According to the results of the study, Yavari [46] has find that the increase in the activities and responsibilities of the employees at work reduces the work-related procrastination behavior of the employees.

\section{Method}

In this study, quantitative methodology was used to answer the question "Does spiritual leadership affect empowerment and work procrastination?". In this context, research hypotheses and theoretical model are created as follows.

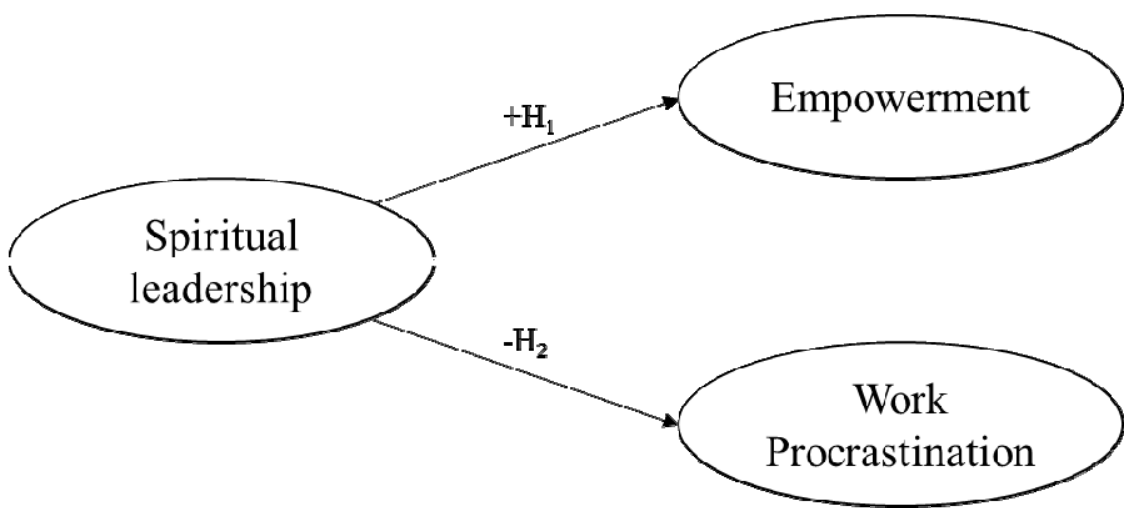

Fig. 1. Theoretical Model

$\mathrm{H}_{1}$ : Spiritual leadership has positive effect on empowerment

$\mathrm{H}_{2}$ : Spiritual leadership has negative effect on procrastination

\subsection{Data collection and sample}

The private sports and fitness center operating in the province of Sakarya constitute the universe of the research. The questionnaire was distributed voluntarily by judgment sampling technique to total of 200 volunteer employees from such organizations as the sample of the research and 113 questionnaire forms were evaluated. The questionnaire was conducted as face to face way. 


\subsection{Data collection tool and scales}

The questionnaire created within the scope of the study consists of four parts. First three parts contain items to determine spiritual leadership, empowerment and procrastination, while the last part contains the items to determine the demographic characteristics of the participants. Information about the measurement tools used in the research is as follows:

Spirituality Leadership Scale; developed by Fry et al. [16] and adapted to Turkish by Kurtar [27] was used, and it consisted of 21 items and 5 sub-dimensions. The subdimensions were vision, hope/faith, altruistic love, meaning/call, membership.

Empowerment Scale; developed by Melhem [29] and adapted to Turkish by Özbek and Gözde [31] was used, and it consisted of 12 items and 3 sub-dimensions. The subdimensions were discretion, control and responsiveness.

Work Procrastination Scale; developed by Dutschmann [10] and adapted to Turkish by Gül [18] was used, and it consisted of 22 items and a sub-dimension.

A five-point scales that ranges from 1- Strongly disagree to 5-Strongly agree was used and the reliability (cronbach alpha) of it was over 0.70 . In the last part of the questionnaire, there were questions about the socio-demographic characteristics of the participants.

\section{Findings}

The findings of the employees' demographic characteristics such as gender, marital status, age, education, work period in the organization in the research are all shown in Table 1 below;

Table 1. Demographic findings $(\mathrm{n}=113)$

\begin{tabular}{|c|c|c|c|}
\hline & & Frekans(n) & Oran (\%) \\
\hline \multirow{2}{*}{ Gender } & Male & 69 & 61,1 \\
\hline & Female & 44 & 38,9 \\
\hline \multirow{3}{*}{ Marital Status } & Married & 53 & 46,9 \\
\hline & Single & 55 & 48,7 \\
\hline & Unanswered & 5 & 4,4 \\
\hline \multirow{7}{*}{ Age } & 18 years and below & 7 & 6,2 \\
\hline & Between 18-24 years & 19 & 16,8 \\
\hline & Between 25-29 years & 37 & 32,7 \\
\hline & Between 30-39 years & 23 & 20,4 \\
\hline & Between $40-49$ years & 21 & 18,6 \\
\hline & Between $50-65$ years & 2 & 1,8 \\
\hline & Unanswered & 4 & 3,5 \\
\hline \multirow{6}{*}{ Education } & $\begin{array}{l}\text { Primary School and } \\
\text { Secondary School }\end{array}$ & 9 & 8 \\
\hline & High School & 28 & 24,8 \\
\hline & Vocational High School & 23 & 20,4 \\
\hline & Bachelor Degree & 39 & 34,5 \\
\hline & Master Degree & 6 & 5,3 \\
\hline & Unanswered & 8 & 7,1 \\
\hline \multirow{6}{*}{ Work period } & Less than 1 year & 14 & 12,4 \\
\hline & $1-3$ years & 28 & 24,8 \\
\hline & $4-6$ years & 31 & 27,4 \\
\hline & $7-9$ years & 17 & 15 \\
\hline & 10 years and over & 21 & 18,6 \\
\hline & Unanswered & 2 & 1,8 \\
\hline
\end{tabular}


A total of 113 people participated in this research, 69 males and 44 females, and $48.7 \%$ of them were single and $46.9 \%$ were married. A significant number of participants are in the range of $25-29$ age $(32,7 \%)$. According to the educational status, $34.5 \%$ of the participants have a bachelor's degree, $24.8 \%$ have a high school and $20.4 \%$ have a vocational high school degree. In addition, $27.4 \%$ of the participants are employees for 4-6 years.

As a result of the explanatory factor analysis, it was determined that the data set was suitable for the factor analysis by the fact that the value of the Kaiser-Meyer-Olkin (KMO) sample adequacy exceeded 0.50 and the tail probability of the Bartlett test was significant at 0.05 significance level.

Table 2. KMO and reliability

\begin{tabular}{|l|l|l|}
\hline $\begin{array}{l}\text { Spirituality Leadership } \\
\text { Scale }\end{array}$ & $\begin{array}{l}\text { KMO=0.750 } \\
\text { Cronbach Alpha }(\alpha=0,704)\end{array}$ & $\begin{array}{l}\text { X'Bartlett: } 655,268 \\
\text { Sd: } 210 \\
\text { tail probability test p: 0,00 }\end{array}$ \\
\hline Empowerment Scale & $\begin{array}{l}\text { KMO=0,801 } \\
\text { Cronbach Alpha }(\alpha=0,702)\end{array}$ & $\begin{array}{l}\mathrm{X}^{2} \text { Bartlett: } 287,855 \\
\text { Sd: } 45 \\
\text { tail probability test p: 0,00 }\end{array}$ \\
\hline Work Procrastination Scale & $\begin{array}{l}\text { KMO=0,608 } \\
\text { Cronbach Alpha }(\alpha=0,765)\end{array}$ & $\begin{array}{l}\mathrm{X}^{2} \text { Bartlett: } 568,981 \\
\text { Sd: } 231 \\
\text { tail probability test p: } 0,00\end{array}$ \\
\hline
\end{tabular}

In this context, sub-dimensions in our study have been defined in the literature, where validity and reliability have been proven before. Spiritual leadership sub-dimensions are defined in literature as vision, hope/faith, altruistic love, meaning/call and membership. Empowerment sub-dimensions are defined as discretion, control, and responsiveness. However, it is deemed necessary to item 4 . and 11. from the analysis because of reliability reduction. Procrastination was made up of a dimension and no item was subtracted from the analysis. The means, standard deviations, and correlation values between the data obtained for the study variables are summarized in Table 3.

Table 3. Means, standard deviations, correlation values of research variables

\begin{tabular}{|l|c|c|c|c|c|c|c|c|c|c|}
\hline & Mean & Sd. & $\mathbf{1}$ & $\mathbf{2}$ & $\mathbf{3}$ & $\mathbf{4}$ & $\mathbf{5}$ & $\mathbf{6}$ & $\mathbf{7}$ & $\mathbf{8}$ \\
\hline Vision & 3,95 & 1,140 & 1 & & & & & & & \\
\hline Hope/faith & 3,92 &, 670 & $0,224^{*}$ & 1 & & & & & & \\
\hline Altruistic Love & 3,85 &, 598 &, $275^{* *}$ &, $480^{* *}$ & 1 & & & & & \\
\hline Meaning/Call & 3,91 &, 668 &, 125 &, $582^{* *}$ &, $475^{*}$ & 1 & & & & \\
\hline Membership & 3,98 &, 613 &, $232^{*}$ &, $521^{* *}$ &, $629^{* *}$ & $606^{* *}$ & 1 & & & \\
\hline Control & 3,16 &, 856 &,- 007 &, 084 &,- 054 &, 167 &, 065 & 1 & & \\
\hline Discretion & 3,29 &, 995 &,- 049 &, 143 &, 142 & $330^{* *}$ &, $265^{* *}$ &, $640^{* *}$ & 1 & \\
\hline Responsiveness & 3,23 &, 577 &, 015 &, 099 &, 008 &, $255^{*}$ &, 098 &, $335^{* *}$ & 177 & 1 \\
\hline Procrastination & 2,64 &, 487 &,- 179 &,- 043 &,- 246 &,- 075 &,- 135 & $, 388^{* *}, 093$ &, 095 \\
\hline$* *$ p $<, 01 ; *$ p $<, 05$
\end{tabular}

According to Table 3, it is possible to say that the mean values of these variables vary between 2,64 and 3,98 and statistically significant relationships between the variables. As a result of the analysis of the obtained data; It was determined that there was a low and positive relationship between "meaning/call" which was the sub-dimension of spiritual leadership and discretion $(\mathrm{r}=.330 ; \mathrm{p}<.01)$ and responsiveness $(\mathrm{r}=.255 ; \mathrm{p}<.05)$ which are the sub dimensions of empowerment. There was a positive and low level relationship between membership and discretion $(\mathrm{r}=.265 ; \mathrm{p}<.01)$. There was a negative relationship between 
procrastination and altruistic love $(\mathrm{r}=-.246 ; \mathrm{p}<.05)$, and positive relationship between procrastination and control $(\mathrm{r}=.388 ; \mathrm{p}<.01)$.

Three regression analyzes were conducted to test the effect of spiritual leadership on empowerment (Table 4). Stepwise method is used in regression analysis.

Table 4. Regression analysis

\begin{tabular}{|c|c|c|c|c|c|c|c|c|c|}
\hline \multirow{3}{*}{$\begin{array}{l}\text { Independent Variable } \\
\text { Spiritual Leadership }\end{array}$} & \multicolumn{9}{|c|}{ Dependent Variable (Empowerment) } \\
\hline & \multicolumn{3}{|c|}{ Control } & \multicolumn{3}{|c|}{ Discretion } & \multicolumn{3}{|c|}{ Responsiveness } \\
\hline & $\beta$ & $\mathrm{t}$ & $\mathrm{p}$ & $\beta$ & $\mathrm{t}$ & $\mathrm{P}$ & $\beta$ & $\mathrm{t}$ & $\mathrm{p}$ \\
\hline Vision & - & - & - & - & - & - & - & - & - \\
\hline Hope/Faith & - & - & - & - & - & - & - & - & - \\
\hline AltruisticLove & - & - & - & ,540 & 4,137 & 0,000 & - & - & - \\
\hline Meaning/call & 217 & 2,034 &, 045 & - & - & - & ,278 & 2,689 & 009 \\
\hline Membership & - & - & - &,- 319 & $-2,443$ &, 017 & - & - & - \\
\hline Anova & \multicolumn{3}{|c|}{$\begin{array}{c}\text { F: } 4,138 \\
\text { Sig. } \alpha:, 045\end{array}$} & \multicolumn{3}{|c|}{$\begin{array}{c}\text { F: } 8,607 \\
\text { Sig. } \alpha:, 000\end{array}$} & \multicolumn{3}{|c|}{$\begin{array}{r}\text { F: } 7,230 \\
\text { Sig. } \alpha:, 009\end{array}$} \\
\hline Adjusted $\mathrm{R}^{2}$ & \multicolumn{3}{|c|}{0,036} & \multicolumn{3}{|c|}{0,150} & \multicolumn{3}{|c|}{0,067} \\
\hline
\end{tabular}

It appears that the spiritual leadership has significantly predicted the control dimension $(3,6 \%)$, which is the empowerment sub-dimension (F:4,138; p:,045). The meaning/call dimension affects the control dimension in the positive direction $(\beta:, 217 ; \mathrm{p}:, 045)$. In addition, the spiritual leadership subdimension, alturistic love and membership has significantly predicted the discretion dimension (15\%), which is the empowerment subdimension (F:8,617; p:,000). Also, the spiritual leadership subdimension, meaning/call has significantly predicted the responsiveness dimension $(6,7 \%)$, which is the empowerment sub-dimension (F:7,230; p:,009).

Finally; altruistic love has negative effect on procrastination $(\beta:-, 269, \mathrm{p}:, 026)$, discretion affects the procrastination negatively $(\beta:-, 291, \mathrm{p}:, 040)$ and control has positive effect on procrastination $(\beta:, 579 ; \mathrm{p}:, 000)$.

\section{Discussion and conclusion}

This research was conducted to evaluate spiritual leadership, empowerment and work procrastination and to determine the structural relationships among the variables.in private sports and fitness centers operating in Sakarya. As a result of the analysis, business becomes meaningful with the feeling of being pleased with the task or job, feeling that they make a difference and being motivated. Therefore, this increases the control over the work $(\beta:, 217 ; \mathrm{p}:, 045)$. Yaghoubi et al. [45] has reached the conclusion that empowerment is moderately related to meaning. Employees have all kinds of information about their work and the level of control over their work increases when they make sense of their work. The fact that managers take care of their employees with reward and appreciation ensure that they are spiritually good. Thus, they help the employees in their spiritual existence in the organization. In other words, employees become a part of the organization. Employees who have proven themselves in the spiritual context will be more comfortable in taking initiative, making decisions and finding solutions in the organization, and therefore will increase efficiency and productive levels. In this case, employees will not hesitate to reveal their potential $(\beta:, 540, \mathrm{p}:, 000)$. However, those who feel themselves belong to the organization have difficulty in deciding alone within the organization because they take care of the group's common interests and well-being. There is a negative relationship between membership and discretion ( $\beta:-, 319, \mathrm{p}:, 017)$. The study of Moradi and 
Shayestehpour [30] support the results we had. Vision, altruistic love, membership, meaning and hope / faith dimensions have a positive effect on empowerment. Managers allow employees to perform more than what is defined in their work with reward and appreciation. So they do not postpone their work and carry out their business in the most sincere and pleasant way. So, in our study, it is concluded that the self-employed who use the initiative to make decisions about their jobs will perform their jobs on time. As a matter of fact, it should not be understood at this point that all the authorization will be delivered to employees. Employees must be given authorization and also responsibility as a result of their decisions. At the same time, it can be stated that employees should be inspected through various audit mechanisms. It is important to pay attention to the consequence that the worker will have an increased control over work behavior, and strategic decisions should be made in this context.

Managers in organizations keep employees under constant control and the inability of employees to make decisions without consulting their senior manager for all decisions hinder the work within the increasing workload, and even those who do not have a connection with their work will escape the responsibility of coming to work late, absenteeism or not finishing their work on time. Therefore, managers who understand their employees, establish emotional ties and deep relationships with them will strengthen their commitment of the work by knowing where, how, when, and in what jobs they will trust their talents.

Thus, the individual who makes sense of work will completely avoid the postponement and procrastination by developing his sense of responsibility as a worker who sees himself as valuable and contributes to the organization's goals.

According to the results obtained from the research; the leaders and managers in organization must ensure that their employees were valued as members of a group that achieve their goals, not as those who work or do business by taking into account the principles of equality and fairness.

In addition, it can be stated that the authority and responsibility are given to the employees together, taking into consideration feedback of the employees in taking the decisions, will increase the motivation of the employees and strengthen them and thus increase the efficiency of the employees.

\section{References}

1. A. C. Akar, Ruhsal liderlik ve ruhsal liderliğin eğitim örgütlerinde uygulanabilirliği hakkında teorik bir çalışma, (Yüksek Lisans), Yeditepe Üniversitesi, İstanbul (2010)

2. S. H. Appelbaum, R. Karasek, F. Lapointe, K. Quelch, Employee empowerment: factors affecting the consequent success or failure-Part I. Industrial and Commercial Training, 46, 7, 379-386 (2014)

3. S. H. Appelbaum, R. Karasek, F. Lapointe, K. Quelch, Employee empowerment: factors affecting the consequent success or failure (Part II). Industrial and Commercial Training, 47, 1, 23-30 (2015)

4. Ş. Arslanoğlu, Lise müdürlerinde liderlik, liderlik düzeylerinin öğretmenlerin motivasyonuna etkisi (konya ili örneği), (Master), Karatay Üniversitesi, Konya (2016)

5. H. Asgarsani, O. Duostdar, A. Rostami, Empowerment and its impact on the organization productivity. Interdisciplinary Journal of Contemporary Research In Business, 1, 11, 25-32 (2013)

6. N. Baloğlu, E. Karadăg, Ruhsal liderlik üzerine teorik bir çözümleme. Kuram ve Uygulamada Eğitim Yönetimi, 58 ,58, 165-190 (2009)

7. A. Bedük, Karşılaştırmalı işletme-yönetim terimleri sözlüğü (3. Basım ed.). Konya: Nobel Yayın (2012) 
8. N. H. Bui, Effect of evaluation threat on procrastination behavior. The Journal of social psychology, 147, 3, 197-209 (2007)

9. I. Cunningham, J. Hyman, C. Baldry, Empowerment: the power to do what? Industrial Relations Journal, 27, 2, 143-154 (1996)

10. S. L. Dutschmann, Procrastination as a predictor of job performance, (Air Force University, Ohio, USA (1996)

11.J. R. Ferrari, Compulsiveprocrastination: Some self-reported characteristics. Psychological reports, 68, 2, 455-458 (1991)

12. J. R. Ferrari, Dysfunctional procrastination and its relationship with self-esteem, interpersonal dependency, and self-defeating behaviors. Personality and Individual Differences, 17, 5, 673-679 (1994)

13. L. W. Fry, Toward a theory of spiritual leadership. The leadership quarterly, 14, 6, 693727 (2003)

14. L. W. Fry, Introduction to the leadership quarterly special issue: Toward a paradigm of spiritual leadership. The leadership quarterly, 16, 5, 619-622 (2005)

15. L. W. Fry, M. P. Cohen, Spiritual leadership as a paradigm for organizational transformation and recovery from extended work hours cultures. Journal of business ethics, 84, 265-278 (2009)

16. L. W. Fry, M. Nisiewicz, S. Vitucci, M. Cedillo. Transforming city government through spiritual leadership: measurement and establishing a baseline. Paper presented at the National Meeting of the Academy of Management, Philadelphia, Pennsylvania (2007)

17. R. Gupta, D. A. Hershey, J. Gaur, Time perspective and procrastination in the workplace: An empirical investigation. Current Psychology, 31, 2, 195-211 (2012)

18. A. Y. Gül, İş yaşamında iş erteleme davranışı ve nedenleri, (Yüksek Lisans Tezi), Dokuz Eylül Üniversitesi, İzmir (2015)

19. Ş. Gündüz, Ruhsal liderlik ile örgütsel sinizm arasındaki ilişki: Duygusal zekânin araci etkisi, (Doktora Tezi), Marmara Üniversitesi, İstanbul (2014)

20. A.-M. Hede, A research agenda for the study of empowerment in hospitality organisations, (Victoria University of Technology (1999)

21. L. Honold, A review of the literature on employee empowerment. Empowerment in organizations, 5, 4, 202-212 (1997)

22. S. Howard, A spiritual perspective on learning in the workplace. Journal of managerial psychology, 17, 3, 230-242 (2002)

23. N. Işık, Liderlik yaklaşımları ve hizmetkâr liderliğin işgörenlerin organizasyonel bağlllıklarına etkileri, (Bahçeşehir Üniversitesi, İstanbul (2014)

24. G. Kerse, C. N. Karabey, Personel güçlendirme ile bireyin yaratıcılık algısı arasındaki ilişki: Bankacılık sektöründe bir uygulama. Akdeniz University Faculty of Economics \& Administrative Sciences Faculty Journal/Akdeniz Universitesi Iktisadi ve Idari Bilimler Fakultesi Dergisi, 14, 29, 22-41 (2014)

25. S. Y. Kim, S. Fernandez, Employee empowerment and turnover intention in the US federal bureaucracy. The American Review of Public Administration, 47, 1, 4-22 (2017)

26. K. B. Klingsieck, Procrastination in different life-domains: is procrastination domain specific? Current Psychology, 32, 2, 175-185 (2013)

27. Ş. Kurtar, Ruhsal Liderlik Ölçeği: Türkçe Dilsel Eşdeğerlik, Geçerlik ve Güvenirlik Çalışması, (Yüksek Lisans Tezi), Yeditepe Üniversitesi, İstanbul (2009)

28. P. Malone, L. W. Fry, Transforming schools through spiritual leadership: A field experiment. Academy of Management, Seattle, WA(2003)

29. Y. Melhem, The antecedents of customer-contact employees' empowerment. Employee Relations, 26, 1, 72-93 (2004) 
30. M. Moradi, J. Shayestehpour, Studying the relation between the spiritual leadership and empowerment of the staff in the organization of research and educational planning. Journal of Applied Environmental and Biological Sciences, 5, 11, 322-331 (2015)

31. M. F. Özbek, K. Gözde, Duygusal Bağl1lık, Örgütsel Destek, Üst Yönetim Desteği ve Personel Güçlendirmenin Hizmet Kalitesi Üzerindeki Etkisi: Kırgızistan'da Banka İşgörenleri Üzerinde Bir Uygulama. Erciyes Üniversitesi İktisadi ve İdari Bilimler Fakültesi Dergisi, 34, 189-212 (2009)

32. S. Polat, T. Tülübaş, Üniversite hazırlık sınıfı öğrencilerine göre öğretim elemanlarının ruhsal liderlik davranışlarını gösterme düzeyleri. Eğitim ve bilim, 38, 170, 32-47 (2013)

33. E. D. Rothblum, L. J. Solomon, J. Murakami, Affective, cognitive, and behavioral differences between high and low procrastinators. Journal of counseling psychology, 33(4), 387 (1986)

34. W. Seaborne, An examination of the relationship between leadership style and empowerment. $\mathrm{PhD}$, Regent university (2003)

35. P. Steel, The nature of procrastination: a meta-analytic and theoretical review of quintessential self-regulatory failure: American Psychological Association (2007)

36. P. Steel, The procrastination equation: How to stop putting stuff off and start getting things done: Murdoch Books (2011)

37. P. Steel, T. Brothen, C. Wambach, Procrastination and personality, performance, and mood. Personality and Individual Differences, 30, 1, 95-106 (2001)

38. M. Ş. Şimşek, A. Çelik, Yönetim ve organizasyon (16. Baskı ed.). Konya: Eğitim Kitabevi (2014)

39. A. Thatcher, G. Wretschko, P. Fridjhon, Online flow experiences, problematic Internet use and Internet procrastination. Computers in Human Behavior, 24, 5, 2236-2254 (2008)

40. Y. Torun, Personel güçlendirme ve işten ayrllma niyeti ilişkisinde örgütsel sinizmin aracılık rolü: Örgütsel sinizm ölçeği geliştirmeye yönelik bir araştırma, (Doktora), Marmara Üniversitesi, İstanbul (2016)

41. P. Tunçer, Örgütsel değişim ve liderlik. Sayıştay Dergisi, 80, 57-83 (2011)

42. B. Uzun, A. Demir, Erteleme: Türleri, bileşenleri, demografik etkenler ve kültürel farklılıklar. Ege Eğitim Dergisi, 16, 1, 106-121 (2015)

43. H. C. Wan, L. A. Downey, C. Stough, Understanding non-work presenteeism: Relationships between emotional intelligence, boredom, procrastination and job stress. Personality and Individual Differences, 65, 86-90 (2014)

44. B. G. Whitaker, J. W. Westerman, Linking spirituality and values to personal initiative through psychological empowerment. Journal of Management, Spirituality \& Religion, 11, 3, 269-291 (2014)

45. N.-M. Yaghoubi, J. Moloudi, S. A. Banihashemi, The relationship between spirituality leadership and empowerment. American Journal of Scientific Research, 12, 180-186 (2010)

46. Y. Yavari, Procrastination and psychological empowerment in sports sciences faculty members. Sport Science-International Scientific Journal of Kinesiology, 9, 2, 54-60 (2016)

47. D. Zeglat, M. Aljaber, W. Alrawabdeh, Understating the impact of employee empowerment on customer-oriented behavior. Journal of Business Studies Quarterly, 6, $1,55-67$ (2014) 